\title{
Latin America's competitive position in knowledge-intensive services trade
}

\author{
Andrés López, Andrés Niembro and Daniela Ramos
}

ABSTRACT

This study presents a dynamic analysis of Latin America's competitiveness in trade in knowledge-intensive services. The methodology used to undertake this analysis is based on the TradeCAN approach developed by the Economic Commission for Latin America and the Caribbean (ECLAC), which provides a means of assessing different countries' competitiveness by looking at their exports to the fastest-growing markets. (In the past, it has usually been applied primarily to exports of goods.) The results suggest that, although some Latin American countries have made inroads in knowledge-intensive service segments and have comparative advantages in them, the percentage of "rising stars" (dynamic sectors in which a country or region is gaining in market share) is still low, while there is a high percentage of "missed opportunities" (dynamic sectors in which a country or region is losing market share). This points up the existence of areas in which the region's competitive position is weak and in which policies are needed to leverage its competitive advantages and remove the obstacles that are holding it back from establishing a more advantageous position in knowledge-intensive service markets.

KEYWORDS

JEL CLASSIFICATION

AUTHORS
Competitiveness, services trade, knowledge-based economy, international trade, exports, trade statistics, Latin America

E01, F14, L80

Andrés López is a researcher at the Research Centre for Industrial Transformation (CENIT/UnTREF), Argentina. anlopez@fund-cenit.org.ar

Andrés Niembro is a researcher at the Interdisciplinary Territorial, Economic and Societal Research Centre (cietes), Universidad Nacional de Río Negro (Andean campus), Argentina, and a doctoral fellow with the National Council for Scientific and Technological Research (CONICET), Argentina. aniembro@unrn.edu.ar Daniela Ramos is a researcher with the Research Centre for Industrial Transformation (cenit/untref), Argentina.danielaramos@fund-cenit.org.ar 


\section{I}

\section{Introduction}

Services have been a dominant sector in the global economy for some time now, as they account for the largest portion of gross domestic product (GDP) and employment in developed economies and in a sizeable part of the developing world as well.

Until recently, however, services were viewed as a low-productivity sector in which there was very little innovation and - with the exception of a limited number of activities such as transport and tourism - very few tradables. Nonetheless, in recent decades the world has witnessed a sea change that has given rise to an entirely new paradigm in service production and trade. As a result, service activities now play an entirely different role in national economies than they did in the past.

Two key factors underlie this transformation. The first is the growing importance of what have come to be known as "knowledge-intensive services". This sector includes a wide range of activities, such as accounting and legal services, audiovisuals, design, advertising, software and information services, research and development (R\&D), health care and education. ${ }^{1}$ What all these activities have in common is that they make intensive use of highly skilled human capital and that information and knowledge are both their inputs and their outputs.

The second major factor is that, while a number of these services were mainly traded in countries' domestic markets until not long ago, now they can be exported. The available statistics do not fully capture this process because of the intangible nature of trade in services and the resulting difficulties in recording service transactions. However, even though the available figures are known to be an underestimate of the true value of trade in services, approximately $20 \%$ of total (goods plus services) world exports are made up of service activities. Even more interestingly, recent estimates based on the use of input-output tables suggest that when trade is measured in terms of value added, the share of

\footnotetext{
${ }^{1}$ Because the focus of this study is competitiveness, the information on knowledge-intensive services is based on the available data on trade in the following segments: business and professional services, software and information services, and audiovisual, cultural and personal services. While these data do not provide full coverage of the knowledge-intensive services sector, they do afford an approximation that is sufficient for the purposes of this study.
}

the services sector verges on 50\% and outweighs trade in manufactures (Escaith, 2008).

The growth of this sector has been led by knowledgeintensive services (see figure 1). Global exports of such services now amount to nearly US\$ 1.6 trillion $^{2}$ (data for 2012 compiled by the United Nations Conference on Trade and Development (UNCTAD)), which is 3.7 times higher than the corresponding figure for 2000. Trade in these services in 2012 outpaced trade in foodstuffs (including raw materials and processed goods), minerals, steel, textiles and clothing, electronics and motor vehicles, to cite only a few examples.

The growth of trade in knowledge-intensive services has gone hand in hand with the deployment of information and communications technologies (ITCs), which have made the generation, processing and transmission of information much less expensive and much faster and have even made it possible to digitize certain types of goods and thus convert them into intangibles. These same ITCs have also made it possible to provide certain types of services remotely that, until recently, could be traded only via direct contact between the service provider and user.

ITCs provide the infrastructure needed for the dispersion of production on a global scale, which has led to the formation of global value chains. Within these chains, production processes are divided up into portions of value added that is generated in different locations. This means that what is important is no longer what is produced where, but rather what processes are carried out where and how much value added they generate (Baldwin, 2011). Transnational corporations play a leading role in organizing most of these global value chains and in offshoring the production of goods and services to locations where costs are competitive and skilled resources can be accessed.

China and India have become world-class magnets for knowledge-intensive services because of their vast reserves of university-trained human resources. Data compiled by UNCTAD indicate that these two countries export over US\$ 90 billion worth of knowledge-intensive

\footnotetext{
2 If insurance and financial services, communications, and royalties and licences are factored in, then the figure climbs to US\$2.35 trillion for 2012.
} 
FIGURE 1

Composition of international services trade, 2000-2012

(Percentages of the total)

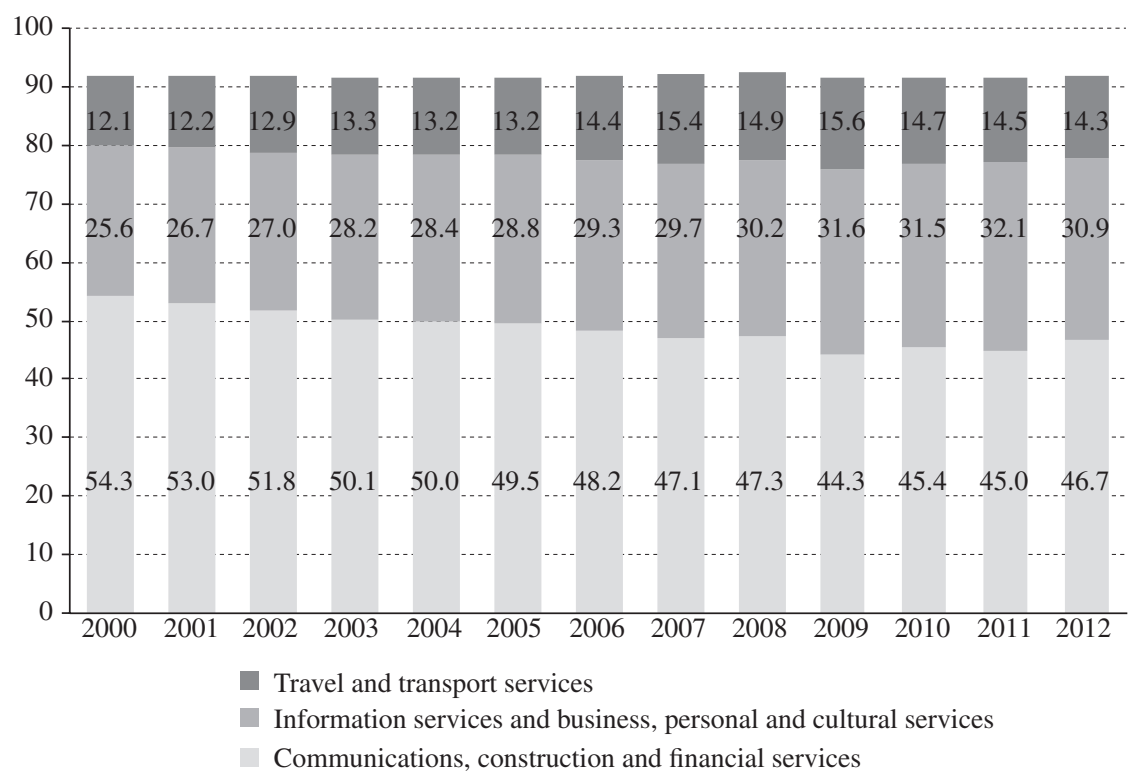

Source: prepared by the authors on the basis of figures from the United Nations Conference on Trade and Development (UNCTAD).

Note: the figures do not add up to $100 \%$ because the categories "royalties and licences" and "government services" have not been included.

services. There are many developing countries that have also positioned themselves in these markets, however, such as Malaysia, the Philippines and Thailand, in Asia, and Poland, the Czech Republic and Hungary, in Eastern Europe, as well as developed-country pioneers such as Ireland.

Latin America has also begun to play an active part in this new area of global trade, and a number of countries in the region (notably Argentina, Brazil, Colombia, Costa Rica, Chile and Uruguay) ${ }^{3}$ have been exporting more and more knowledge-intensive services.

Moving beyond the information provided by trade statistics, the question to be answered is how competitive the region is in knowledge-intensive service markets. The concept of "international competitiveness" involves many different factors and has been the object of a wide range of different conceptualizations and approaches. Given the difficulties involved in arriving at a single, agreed definition, for the purposes of this

\footnotetext{
${ }^{3}$ Mexico does not compile statistics on exports of knowledge-intensive services other than audiovisual services. For this reason, it is not included in a number of the statistical tables presented in this study.
}

study the concept of competitiveness can be, generally speaking, seen as corresponding to the (relative) performance of a given firm, sector or country in the international economy. A number of indicators have been developed on this basis as a means of comparing the relative performance of different countries/firms in world markets.

Although it is becoming more and more common to view international competitiveness as part of a structurally, systemically and otherwise complex, dynamic process that entails an interaction of micro-, meso- and macroeconomic factors, most of the studies that have been done to date on the competitiveness of different countries in international services trade have focused on the "revealed comparative advantages" indicator (see, for example, Langhammer, 2004; Díaz de la Guardia, Molero and Valadez, 2005; Bobirca and Miclaus, 2007; Seyoum, 2007; Zhang, Wei and Miao, 2010; Jiang, 2011). This type of methodological approach entails an ex post calculation (for a given point in time) of an economy's degree of specialization in world trade and is based on an essentially static view of comparative advantages (Ferraz, Kupfer and Haguenauer, 1996). As noted by 
Chudnovsky and Porta (1990, pp. 13-15), this traditional concept of static comparative advantages is not very useful, however, when the objective is to determine the areas in which action might be taken to create dynamic advantages ${ }^{4}$ or to derive greater benefit from international trade.

This study takes an alternative approach to the analysis of Latin America's competitive position in international markets for knowledge-intensive services based on an ex post examination of outcomes. The focus is on determining how effective the region's patterns of specialization are in enabling it to take advantage of the

\footnotetext{
${ }^{4}$ For a more in-depth analysis, see, for example, Ffrench-Davis (1990).
}

opportunities that open up in world markets. An effort is also made to delve into the factors underlying the observable trends in this area.

The following discussion is organized as follows. Section II presents a brief analysis of trends in world exports and, more specifically, in Latin American exports of knowledge-intensive services over the past decade. Section III, which is the core component of this study, focuses on the region's competitive position in trade in knowledge-intensive services based on the Tradecan methodology. Section IV briefly reviews the main ex ante determinants of competitiveness in knowledge-intensive service sectors and highlights certain aspects of the region's position in those markets. The fifth and final section presents the study's findings.

\section{II}

\section{The role of Latin America in knowledge- intensive services trade}

Before taking a brief look at trends in world and Latin American trade in services in recent years, a few comments regarding trade statistics are in order. It is well known that the statistics on trade in these kinds of services do not provide an accurate picture of the volumes that are actually involved. Some of the reasons for this are: (i) many of these services are new types of activities, and there is as yet no consensus as to how they should be measured; (ii) many of these exports are intangible, which makes it hard to keep records on them; and (iii) international trade in services occurs in various ways that are not always captured fully or in any standardized manner in official statistics (López, Ramos and Torre, 2009). These difficulties are heightened by the fact that a large part of services trade is made up of intra-firm transactions that are conducted on the basis of transfer prices and that are sometimes not recorded at all because of taxation, accounting or other types of considerations. The available statistics are also not sufficiently disaggregated to serve as a basis for a detailed analysis of trade in knowledge-intensive services.

These difficulties notwithstanding, there is still enough information at hand to undertake an analysis of this type and to arrive at useful findings regarding Latin
America's position in knowledge-intensive services and its levels of competitiveness. ${ }^{5}$

Since the General Agreement on Trade in Services (GATS) was signed in the mid-1990s, international trade in services has been divided into four categories: mode 1, cross-border supply (often linked to ICT transactions); mode 2, consumption abroad (i.e. when clients travel to the country of origin to obtain the service, as when people travel to other locations in order to receive medical treatment); mode 3, commercial presence, which entails the supplier's presence on foreign soil, usually via foreign direct investment (FDI); and mode 4, presence of a natural person, which involves the movement of people (i.e. the service providers) to the country where the destination market is located. One example of this is what has come

\footnotetext{
5 The different countries of the region have made very uneven progress in the collection of information on services trade, and their statistics differ significantly in terms of their level of disaggregation and their coverage. UNCTAD statistics have therefore been used in this study, as they provide a more homogenous basis for cross-country comparisons. A more in-depth analysis of data at the country level for more specific segments of the knowledge-intensive services sector will thus remain a subject for future studies.
} 
to be known as "body shopping", which is the way that the Indian software industry initially made its way into international markets.

Most of the transactions in most types of services that are registered in balance-of-payments statistics are almost entirely mode- 1 transactions. Mode- 2 and mode- 4 transactions are often (erroneously, in many cases) lumped into a single category under the heading of "travel" (which includes tourism income and expenditure). In other words, the second and fourth modes are generally not accurately reflected in official figures because many of these activities are not recorded directly or are misreported because of the inaccurate classification of the movements of the persons concerned (as in the case, for example, of medical tourism or of educational services provided to foreign nationals in the country that is compiling the statistics). The other category of transactions - "commercial presence" — is linked to FDI flows and stocks. ${ }^{6}$ In addition, there are many services (engineering, design, marketing and others) that are embedded in physical goods and are thus registered in the sales of those products.

This study focuses on mode- 1 service transactions, which climbed from US\$ 1.5 trillion in 2000 to US\$ 4.4 trillion in 2012, with US\$ 1.6 trillion of that sum being accounted for by knowledge-intensive services (according to data compiled by UNCTAD). While the cumulative annual growth rate for trade in services for 2000-2011 was only slightly higher than the rate for goods $(9.3 \%$ versus $9.1 \%)$, the growth rate for knowledgeintensive services trade was far higher (11.6\%). During the international financial crisis, services directly linked to trade in goods (transport and financial services) and tourism were the ones that witnessed the steepest declines, whereas business, professional and technical services expanded even during the crisis (Borchert and Mattoo, 2010). Along the same lines, data compiled by consultancies and international organizations indicate that trade in the information technology outsourcing (ITO) and business process outsourcing (BPO) segments - the two largest categories, by volume, of knowledgeintensive services - continued to grow during this period of international turbulence (Gereffi and Fernández-Stark, 2010b; Muthal, 2011).

What is the situation in Latin America? The region (and this includes the Caribbean) has no more

\footnotetext{
6 Foreign affiliates statistics (FATS) can be used to measure mode-3 services trade.
}

than a small share of the global market for knowledgeintensive services (2.9\% in 2012), although that share has grown slightly since 2000 (when it was $2.3 \%$ ). This is a far cry from the share of developing Asian countries (27\% en 2012) $)^{7}$ (figures from the UNCTAD database). In addition, the region's service exports are largely made up of traditional services (transport and travel), although the relative share of knowledge-intensive services has been growing over the past decade. The greatest differences in absolute terms between the region's averages and world averages are in the categories of royalties and licences (the region is not a technology exporter) and financial services (see table 1), which are not included in the category of knowledge-intensive services as defined for the purposes of this study. Using this definition, knowledgeintensive services made up $26.6 \%$ of Latin American service exports in 2010, while the world average is $29.3 \%$.

Table 2 shows the ranking of the main exporting countries in some of the segments of interest here (it also includes all the Latin American countries for which data are available). India leads the list of developing countries for exports of computer services (and is, in fact, the world's top exporter in this category), while China is the leader in other business services (which include BPO, the biggest global offshore services market). China is ranked as the sixth-largest exporter for computer services while India is in twelfth place for exports of business services. In Latin America, Brazil is a major exporter of business services (it is in eighteenth place in the international ranking). Argentina is ranked as the twenty-fourth-largest exporter of computer services (and tops the Latin American list) and the thirty-fourth-largest exporter of business services. Chile, Costa Rica, Colombia and Uruguay are further down in the rankings (with differing positions and significant differences in sales levels). For personal, cultural and recreational services (including health care, education, audiovisuals and other services), Hungary and Turkey are in the top 10. In this case too, Argentina is the largest Latin American exporter (in nineteenth place in the world ranking).

\footnotetext{
7 The gap is even wider in the case of industrial exports, in which the share of Latin America and the Caribbean in the global market amounts to $4.3 \%$ while developing Asia's comes to $37.1 \%$ (UNCTAD database).
} 
TABLE 1

World and Latin American service exports, 2000-2010

(Composition and cumulative annual growth rate (CAGR), in percentages)

\begin{tabular}{|c|c|c|c|c|c|c|c|c|}
\hline \multirow{3}{*}{ Category } & \multicolumn{4}{|c|}{ World exports } & \multicolumn{4}{|c|}{ Latin American exports } \\
\hline & \multicolumn{3}{|c|}{ Percentage of total } & \multirow{2}{*}{$\begin{array}{c}\text { CAGR } \\
(2000-2010)\end{array}$} & \multicolumn{3}{|c|}{ Percentage of total } & \multirow{2}{*}{$\begin{array}{c}\text { CAGR } \\
(2000-2010)\end{array}$} \\
\hline & 2000 & 2005 & 2010 & & 2000 & 2005 & 2010 & \\
\hline Transport & 22.6 & 22.3 & 20.7 & 8.7 & 19.8 & 22.7 & 21.2 & 8.8 \\
\hline Travel & 31.6 & 27.2 & 24.9 & 7.1 & 47.0 & 46.7 & 40.1 & 6.4 \\
\hline Communications & 2.1 & 2.2 & 2.4 & 11.1 & 5.4 & 3.5 & 2.9 & 1.6 \\
\hline Financial services and insurance & 7.9 & 8.6 & 9.2 & 11.3 & 6.7 & 4.5 & 5.5 & 6.0 \\
\hline Construction & 1.9 & 2.1 & 2.3 & 12 & 0.5 & 0.1 & 0.1 & -6.9 \\
\hline Computer and information services & 2.8 & 3.3 & 4.4 & 14.7 & 0.6 & 1.2 & 2.8 & 25.5 \\
\hline Royalties and licences & 6.0 & 6.2 & 6.5 & 10.6 & 0.9 & 0.6 & 0.9 & 7.9 \\
\hline Other business services & 21.0 & 21.9 & 24.1 & 11.2 & 14.6 & 16.3 & 23.0 & 13.1 \\
\hline Personal, cultural and recreational services & 0.9 & 0.8 & 0.7 & 7.3 & 1.0 & 1.2 & 0.7 & 5.2 \\
\hline Government services (+ residual) & 3.2 & 5.4 & 4.8 & 14.3 & 3.5 & 3.2 & 2.8 & 5.8 \\
\hline
\end{tabular}

Source: prepared by the authors on the basis of figures from the United Nations Conference on Trade and Development (UNCTAD).

TABLE 2

Major exporters of knowledge-intensive services, 2010

(Millions of dollars)

\begin{tabular}{|c|c|c|c|c|c|c|c|c|}
\hline \multicolumn{3}{|c|}{ Computer and information sciences } & \multicolumn{3}{|c|}{ Other business services } & \multicolumn{3}{|c|}{ Personal, cultural and recreational services } \\
\hline 1 & India & 56701.2 & 1 & United States & 100476.0 & 1 & United States & 14563.9 \\
\hline 2 & Ireland & 37250.8 & 2 & Germany & 74399.5 & 2 & United Kingdom & 4080.6 \\
\hline 3 & Germany & 16305.0 & 3 & United Kingdom & 73416.8 & 3 & Canada & 2198.3 \\
\hline 4 & United States & 13830.2 & 4 & China & 61241.6 & 4 & France & 1965.4 \\
\hline 5 & United Kingdom & 11518.5 & 5 & Singapore & 43851.3 & 5 & Spain & 1774.7 \\
\hline 6 & China & 9256.3 & 6 & Japan & 42547.4 & 6 & Malta & 1382.7 \\
\hline 7 & Israel & 7699.5 & 7 & Switzerland & 38879.6 & 7 & Luxembourg & 1352.2 \\
\hline 8 & Sweden & 6660.5 & 8 & Netherlands & 32947.8 & 8 & Hungary & 1259.5 \\
\hline 9 & Spain & 6407.6 & 9 & France & 32603.4 & 9 & Germany & 1074.1 \\
\hline 10 & Netherlands & 6155.1 & 10 & Ireland & 29705.5 & 10 & Turkey & 912.0 \\
\hline 21 & France & 1398.6 & 12 & India & 28984.6 & 19 & Argentina & 355.8 \\
\hline 24 & Argentina & 1248.5 & 18 & Brazil & 15776.5 & 21 & India & 334.6 \\
\hline 26 & Costa Rica & 1070.7 & 34 & Argentina & 3910.0 & 32 & China & 122.9 \\
\hline 43 & Brazil & 209.8 & 41 & Chile & 1865.4 & 34 & Brazil & 108.3 \\
\hline 46 & Uruguay & 179.8 & 52 & Costa Rica & 688.5 & 38 & Chile & 86.8 \\
\hline 53 & Chile & 90.7 & 55 & Colombia & 612.1 & 39 & Colombia & 84.2 \\
\hline 57 & Colombia & 45.9 & 58 & Paraguay & 544.2 & 41 & Mexico & 80.0 \\
\hline 66 & Panama & 24.8 & 66 & Peru & 333.3 & 61 & Paraguay & 14.0 \\
\hline 67 & Peru & 20.9 & 76 & Panama & 202.6 & 64 & Honduras & 11.7 \\
\hline 69 & Guatemala & 11.7 & 79 & Uruguay & 180.4 & 68 & $\begin{array}{l}\text { Venezuela (Bolivarian } \\
\text { Republic of) }\end{array}$ & 6.0 \\
\hline 72 & $\begin{array}{l}\text { Venezuela (Bolivarian } \\
\text { Republic of) }\end{array}$ & 9.0 & 81 & $\begin{array}{l}\text { Venezuela (Bolivarian } \\
\text { Republic of) }\end{array}$ & 155.0 & 71 & Peru & 3.9 \\
\hline 77 & Honduras & 4.5 & 90 & Guatemala & 69.6 & 75 & $\begin{array}{l}\text { Bolivia (Plurinational } \\
\text { State of) }\end{array}$ & 1.7 \\
\hline 78 & Paraguay & 4.4 & 100 & El Salvador & 29.6 & 82 & Uruguay & 0.4 \\
\hline 86 & El Salvador & 0.7 & 106 & $\begin{array}{l}\text { Bolivia (Plurinational } \\
\text { State of) }\end{array}$ & 16.6 & 84 & Costa Rica & 0.1 \\
\hline 87 & $\begin{array}{l}\text { Bolivia (Plurinational } \\
\text { State of) }\end{array}$ & 0.7 & 111 & Honduras & 10.3 & 86 & El Salvador & 0.01 \\
\hline
\end{tabular}

Source: prepared by the authors, on the basis of figures from the United Nations Conference on Trade and Development (UNCTAD). 


\section{III}

\section{The competitiveness of knowledge-intensive services exports in Latin America}

As noted earlier, the objective of this study is to evaluate Latin America's competitive position in the international market for knowledge-intensive services and to provide new evidence regarding its pattern of trade specialization and (dynamic) comparative advantages in these activities.

One approach that is frequently used when making sectoral comparisons (and policy decisions) is to focus on the services that generate the greatest value added. While a number of contributions have been made to this area of research -including, for example, the ranking proposed by Gereffi and Fernández-Stark (2010a and 2010b) based on the intensity of the value added by different service activities and the use of that information to graph the situation in Argentina by López, Niembro and Ramos (2011), or its dynamic application (for four countries) by Fernández-Stark, Bamber and Gereffi (2011) — the fact remains that, given the scarcity of information and, in particular, the high level of aggregation of the available data, there is not a sufficient basis, at this stage, to make the jump from case studies to more generally applicable comparisons. Accordingly, the above-mentioned studies draw upon research done in the field and analyses of the literature and other secondary sources on the situation in each country or sector.

Studies have also been conducted that provide a comparative analysis of the situation in knowledgeintensive service sectors in different countries of the region (López, Ramos and Torre, 2009; López and Ramos, 2010), while others draw upon the available evidence in the theoretical and empirical literature to assess the position occupied by Latin America in the various areas that have an impact on its competitiveness in those sectors (López and Ramos, 2013).

Another approach is to examine trade statistics and some of the indicators that are commonly used in the literature. The revealed comparative advantage index ${ }^{8}$ is one of the main indicators of this type which, despite

8 This is a variant of an export indicator; others are based on trade balances. its limitations, can serve as a point of departure for an examination of the specialization patterns of major exporters (see table 3). ${ }^{9}$

As is to be expected, India, Ireland and Israel (the "three I's", as they are known in the literature on this industry) are the leaders in computer services, while a number of developing countries - especially in Asia - are the top-ranked exporters of business services. Developing countries, including transition economies, are even more prominent in personal, cultural and recreational services. In Latin America, Costa Rica, Argentina and Uruguay are leaders in software, while Brazil is in the number-one spot in other business services and Argentina is in fifth place for personal, cultural and recreational services. This indicates that some of the Latin American countries do have comparative advantages in the markets for knowledge-intensive services, even though, for various reasons (especially the size of their economies), they do not rank among the world's top exporters in those segments.

In short, although the Latin American countries have no more than a small share of world trade in services overall, there are a number of success stories in which countries have managed to consolidate their comparative advantages and gain entry into dynamic knowledge-intensive service markets.

As mentioned earlier, the revealed comparative advantages indicator has various limitations, including

9 This index is computed on the basis of the following formula:

$$
V C R_{i j}=\frac{X_{i j} / \sum_{i} X_{i j}}{\sum_{j} X_{i j} / \sum_{i} \sum_{j} X_{i j}}
$$

where $X_{i j}$ represents service exports $i$ from country $j$. The numerator thus represents a given sector's share of a country's total service exports, while the denominator reflects that sector's share of world service exports. When $V C R_{i j}$ is greater than unity, then country $i$ has comparative advantages in service $j$. If $V C R_{i j}$ is between 1 and 2 , then the country is said to have a weak comparative advantage; if it is between 2 and 3 , it is said to have a strong comparative advantage; and if it is greater than 3 , then its comparative advantage is classified as being very strong. 


\begin{tabular}{|c|c|c|c|c|c|c|c|c|}
\hline \multicolumn{3}{|c|}{ Computer and information services } & \multicolumn{3}{|c|}{ Other business services } & \multicolumn{3}{|c|}{ Personal, cultural and recreational services } \\
\hline 1 & India & 7.9 & 1 & Brazil & 2.1 & 1 & Malta & 32.9 \\
\hline 2 & Ireland & 6.6 & 2 & Philippines & 2.0 & 2 & Hungary & 6.3 \\
\hline 3 & Israel & 5.4 & 3 & Taiwan Province of China & 2.0 & 3 & Serbia & 4.8 \\
\hline 4 & Costa Rica & 4.4 & 4 & Switzerland & 1.9 & 4 & Canada & 3.0 \\
\hline 5 & Finland & 4.2 & 5 & Sweden & 1.7 & 5 & Argentina & 2.6 \\
\hline 6 & Philippines & 2.8 & 6 & Singapore & 1.6 & 6 & United States & 2.5 \\
\hline 7 & Sri Lanka & 1.9 & 7 & Paraguay & 1.5 & 7 & Turkey & 2.5 \\
\hline 8 & Romania & 1.8 & 8 & Bermuda & 1.5 & 8 & New Zealand & 2.4 \\
\hline 9 & Sweden & 1.8 & 9 & China & 1.5 & 9 & Azerbaijan & 2.2 \\
\hline 10 & Argentina & 1.6 & 10 & Belgium & 1.5 & 10 & Luxembourg & 1.9 \\
\hline 11 & Uruguay & 1.2 & 22 & Argentina & 1.2 & 11 & Colombia & 1.8 \\
\hline 51 & Colombia & 0.2 & 46 & Chile & 0.7 & 21 & Honduras & 1.1 \\
\hline 55 & Chile & 0.1 & 52 & Costa Rica & 0.7 & 25 & Paraguay & 0.9 \\
\hline 62 & Peru & 0.1 & 68 & $\begin{array}{l}\text { Venezuela (Bolivarian } \\
\text { Republic of) }\end{array}$ & 0.4 & 42 & Mexico & 0.5 \\
\hline 63 & Guatemala & 0.1 & 69 & Peru & 0.4 & 51 & $\begin{array}{l}\text { Venezuela (Bolivarian } \\
\text { Republic of) }\end{array}$ & 0.3 \\
\hline 64 & $\begin{array}{l}\text { Venezuela (Bolivarian } \\
\text { Republic of) }\end{array}$ & 0.1 & 74 & Uruguay & 0.3 & 52 & Brazil & 0.3 \\
\hline 67 & Honduras & 0.1 & & & & 63 & Peru & 0.1 \\
\hline
\end{tabular}

Source: prepared by the authors, on the basis of figures from the United Nations Conference on Trade and Development (UNCTAD).

the fact that it provides a basis only for a static analysis of competitiveness. One way of getting around this limitation is to differentiate trade patterns on the basis of the dynamism of the international markets concerned. As pointed out by Porta (2005, pp. 12-13), bringing (upward, stagnant or downward) trends in world demand into the equation opens up the possibility of taking another look at certain aspects of production and marketing specialization, whereupon it becomes possible to take into account the fact that some shortcomings in terms of international competitiveness could be the result of a country's weak or unsuitable patterns of trade specialization. Bianco (2007) notes that an economy's increasing involvement in sectors or activities (or both) that have expanding external markets constitutes an indicator of structural competitiveness gains.

An approach to the analysis of international competitiveness that fits in with the objectives of this study (and that, as will be shown, can accommodate the types of statistics that are available) is the TradecAn (Trade Competitive Analysis of Nations) methodology, which was developed in 1990 by the Economic Commission for Latin America and the Caribbean (ECLAC), mainly for use in analysing countries' competitiveness in merchandise trade. ${ }^{10}$ This methodology can be used to obtain a dynamic picture of countries' competitive positions by gauging the extent to which a country manages (or fails) to increase its market share in sectors that are attracting an increasing level of international demand. These patterns can be divided into four categories: (i) "rising stars": dynamic sectors (their share in total world imports is expanding) in which a country's market share is growing; (ii) "declining stars": stagnant or declining sectors (their percentage share of world imports is shrinking) in which a country's market share is expanding; (iii) "missed opportunities": dynamic sectors in which a country's market share is shrinking; and (iv) "retreats": stagnant or declining sectors in which a country's market share is also declining.

This classification thus reflects both the growth of the various sectors and the increase or decrease in a country's market share between 2000 and 2009 based on the data compiled by UNCTAD on imports and exports

\footnotetext{
10 It should be pointed out that analyses based on the TradecaN methodology do not provide information on the reasons why countries may have gained or lost international market shares.
} 
in the main segments of the services sector. ${ }^{11}$ In terms of the first of these two dimensions, the sectors that were on the decline during this period (as measured by the percentage of total world imports that they account for) were: transport, travel, and personal, cultural and recreational services. The sectors that came to account for a larger share of total international trade were: communications, construction, insurance, financial services, computer and information services, royalties and licences, and other business services.

Clearly, the data used in this exercise are highly aggregated, and it is quite possible that different subcategories of the main segments have trended in different ways. If this is the case, then some segments could be dynamic while others could be on the decline, so the aggregate figures would not provide an accurate reflection of the status of its components. This issue will be discussed further later on in this study.

The aforementioned reservations notwithstanding, figure 2(a) shows what percentage of the TradecAN categories of service exports came from Latin American countries in 2009. Even today, the bulk of the region's exports are concentrated in stagnant or declining sectors of global trade (declining stars and retreats), while the number of rising stars (dynamic sectors in which a country

11 The available data are subject to the same flaws in terms of the compilation of statistics that were mentioned earlier (including the failure of certain categories of activities to report their figures in some countries). or region is gaining in market share) is, in most cases, quite limited, except in the cases of Brazil, Argentina and Costa Rica, where this category accounts for at least $40 \%$ of service exports. In a number of countries in the region, a considerable share of exports fall into the missed opportunities category, i.e. dynamic segments in the international economy in which the countries' market share is shrinking.

The pattern for Latin America is thus at odds with the patterns for other developing and emerging regions that have succeeded in taking greater advantage of the growth of world trade in services and of opportunities for offshoring services and have thus managed to become a part of these global value chains. As shown in figure 2(b), Asian countries and, to a lesser extent, those of Eastern Europe have a higher percentage of rising-star exports and a fairly small share of missed-opportunity exports. The situation is much the same in the case of developed countries such as Ireland, Finland, Sweden and Germany. Other developed countries such as the United States, the United Kingdom, France and Japan have a higher percentage of missed-opportunity exports, which shows that, although a large part of their exports are still in dynamic world service segments, during the 2000s their market shares in those sectors have been shrinking as these activities are offshored to other countries. The other side of the coin is reflected in the developing and some developed countries' rising stars.

As mentioned earlier, the various subcategories of services may exhibit differing trends that could be

FIGURE 2

\section{Service exports in 2009, by TradecAN categories for 2000-2009}

(Percentages of the total)

(a) Latin America

(b) Selected countries outside Latin America
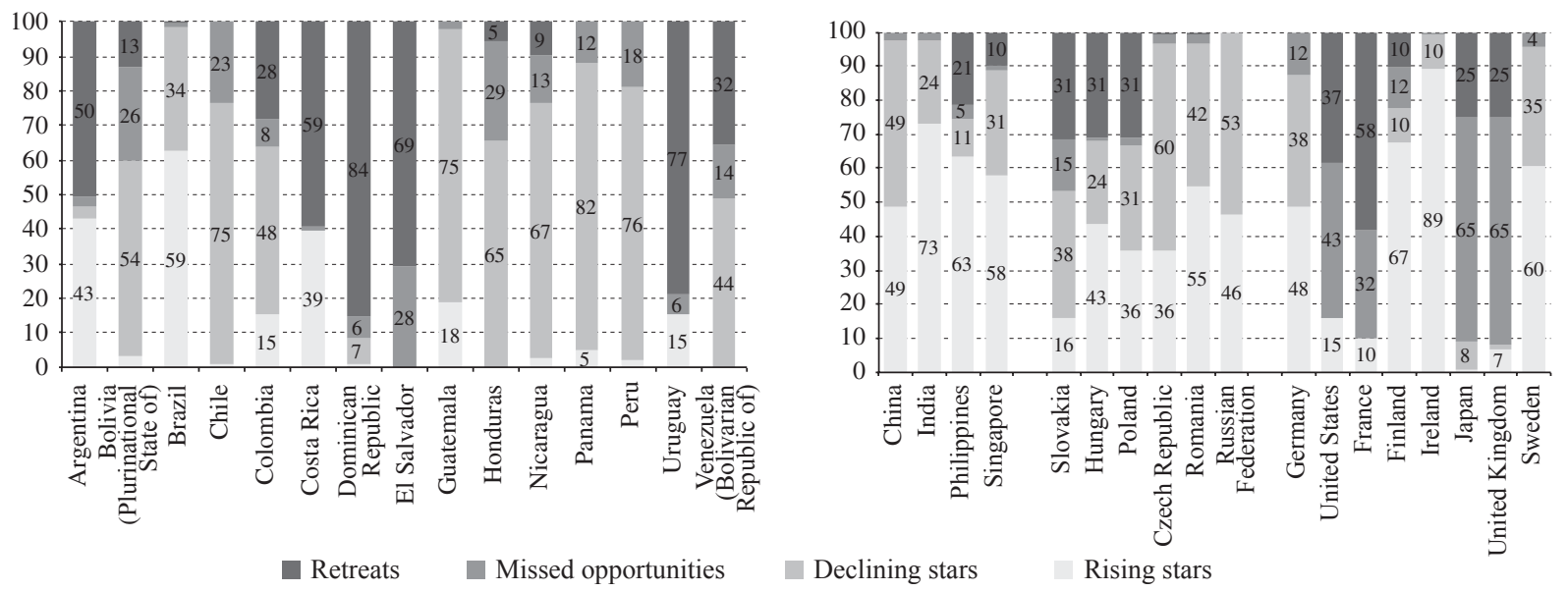

Source: prepared by the authors, on the basis of data from the United Nations Conference on Trade and Development (UNCTAD). 
masked or obscured by the overall trends in the major categories for which figures are being given. Table 4 provides a basis for an at least partial analysis of the trends in the various service subsegments by showing how the share of services in total imports has varied in selected major import markets. ${ }^{12}$ This approach brings out some interesting issues.

12 This is referred to as a "partial analysis" because, in contrast to the preceding discussion, the available data on these activities do not provide a full picture of the world market. Another factor to be taken into account is that the data used in the comparison are for different years because the periods for which data have been compiled by the various sources do not coincide.
First of all, although in earlier sections of this study the category of "personal, cultural and recreational services" was classified as a sector with a shrinking share of the total market, it turns out that this is not necessarily true of all the subcategories and markets included under this heading. For example, the United States is a highly dynamic market for exports of audiovisual and related services (and the relative level of these imports has also been on the rise in the United Kingdom). In addition, the share of total service imports represented by other personal, cultural and recreational services has climbed for the European Union as a whole (and this is especially true for Portugal).

TABLE 4

Service imports in selected markets, by category and subcategory, 2004-2008 (Percentage variation)

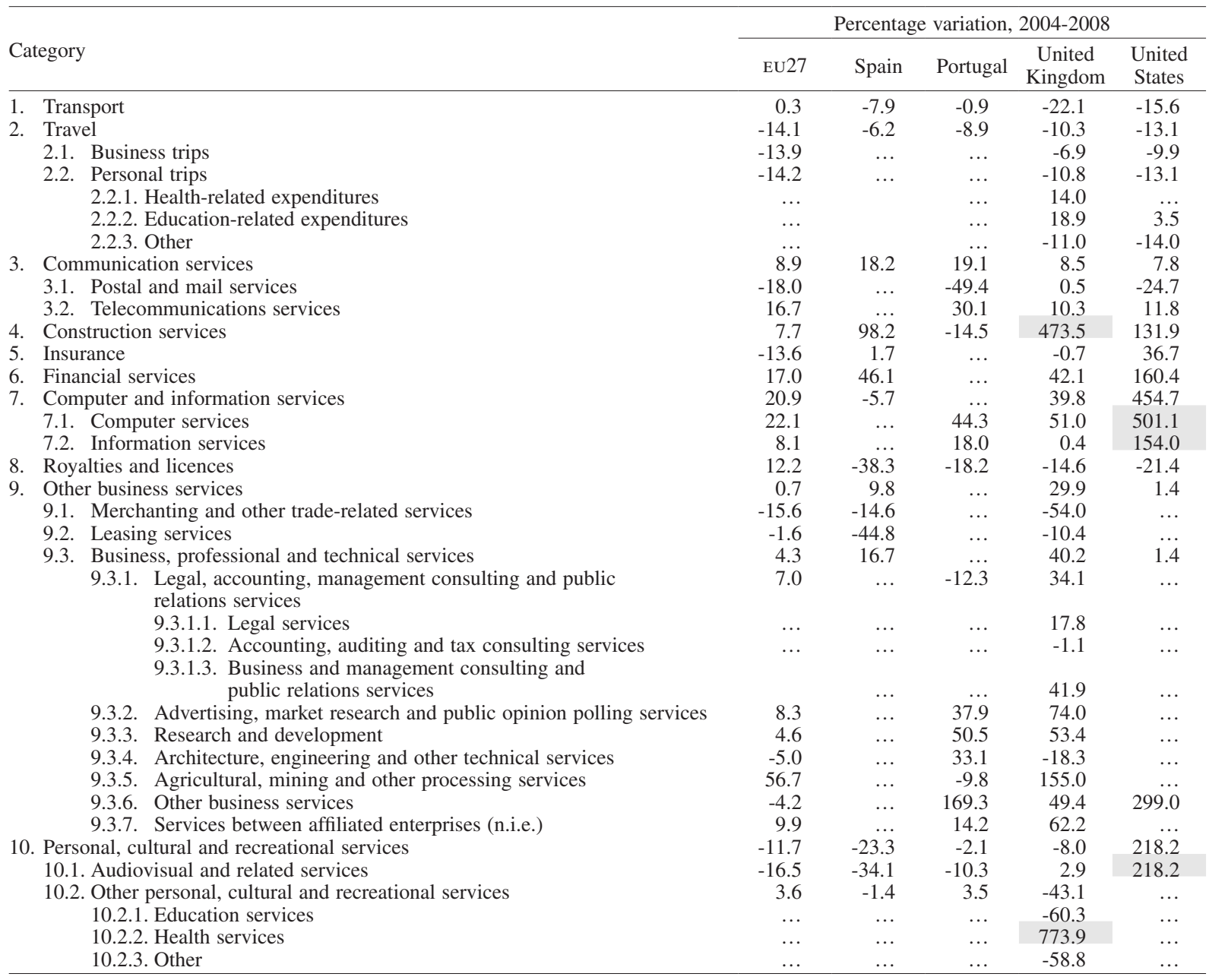

Source: prepared by the authors, on the basis of United Nations Service Trade.

EU-27: the 27 economies that form part of the European Union.

n.i.e: data that are not included elsewhere. 
Second, there are also significant differences between some components of the category "other business services". For example, while advertising, market research, and research and development (R\&D) are buoyant markets, imports in the subsegment of architecture, engineering and technical services are on the decline in the European Union and the United Kingdom.

Third, there are some destinations that are particularly strong for certain types of service exports: the United States is such a destination for computer and information services and, as mentioned earlier, for audiovisual services, while the United Kingdom is an especially important market for construction and health services (a portion of health services is also linked to the category of travel). This reading of the data should be used for purposes of illustration only, however, since information at this level of details is not available for many destinations/sectors. For example, disaggregated data on health service exports is unavailable for the United States, even though it is known that the United States is a key market for such exports (López and others, 2010).

Figure 3 shows a different way of analysing the figures that affords a new perspective on some of the results of the preceding TradecAN exercise that had cast the region in an unfavourable light. This approach makes it possible to differentiate among certain types of services and to identify countries that not only expanded their share of total world exports in those markets, but also increased those segments' share in the corresponding country's total service exports for 2000-2009.

Market share of knowledge-intensive services exports for Latin America and selected countries, 2000-2009

(Percentage variation)

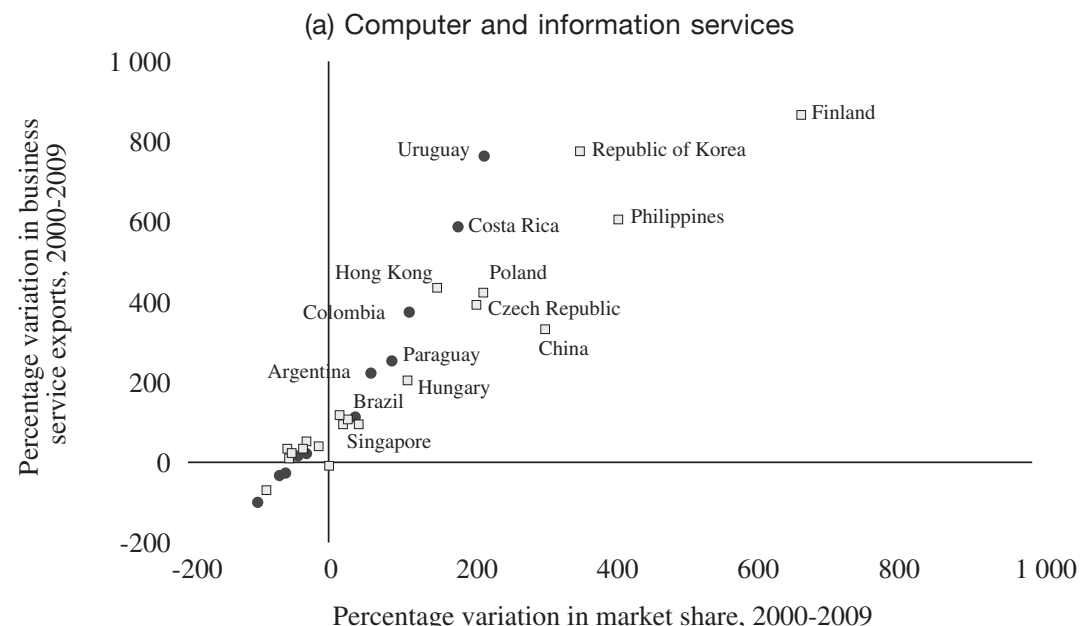

(b) Other business services

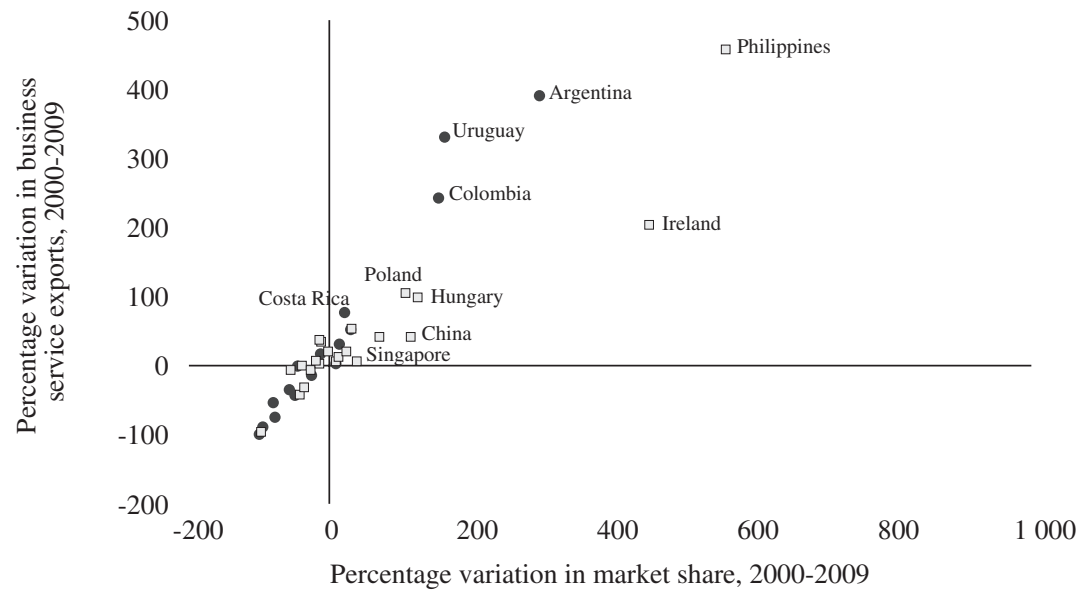


(c) Personal, cultural and recreational services

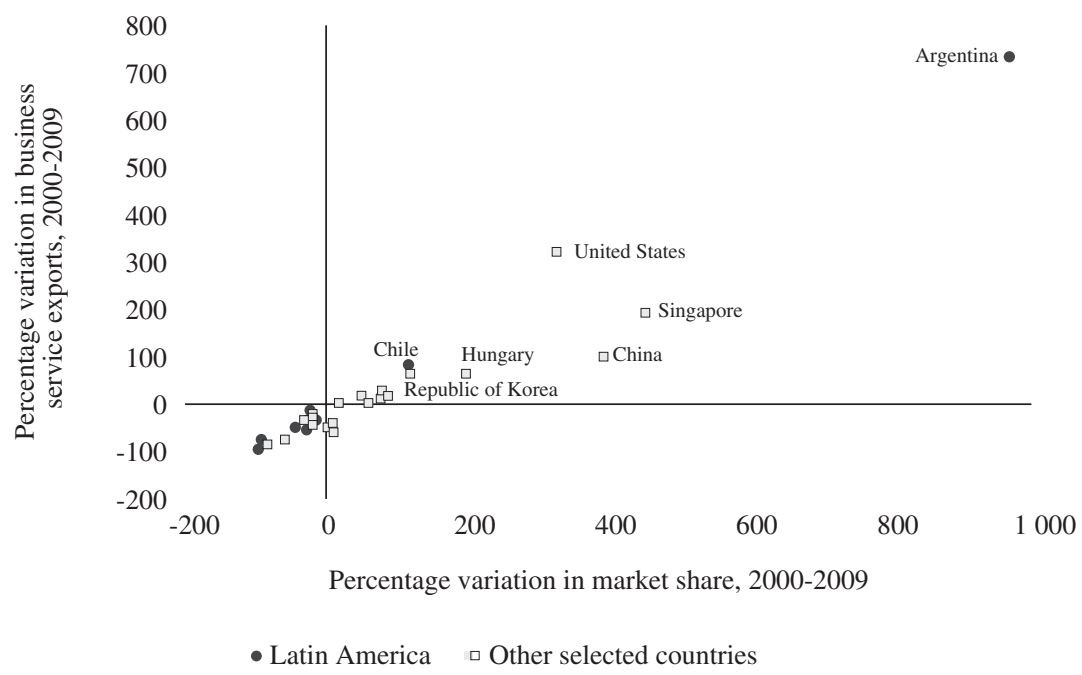

Source: prepared by the authors, on the basis of data from the United Nations Conference on Trade and Development (UNCTAD).

As can be seen from the figure, a number of Latin American countries became increasingly specialized in exports of knowledge-intensive services during the 2000s and increased their share in the world market for those segments, with an overall positive trend being exhibited in both dimensions. In many cases, this trend has matched up with trends in other developed- and developing-country competitors.

Reference can also be made to gains in competitiveness, disaggregated by the various markets for Latin American service exports. These data have been generated by an analysis based on the TradecAN methodology, ${ }^{13}$ but with the difference that the most dynamic importing countries/markets for "other commercial services" are singled out ${ }^{14}$ (i.e. those in which the share of total service imports represented by this category of imports expanded between 2006 and 2008); the data are also broken down by the extent of changes in the different Latin American countries'

13 The four quadrants shown in this figure correspond to those used in the more conventional TradecAN structure

\begin{tabular}{|c|c|}
\hline MISSED OPPORTUNITIES & RISING STARS \\
\hline RETREATS & DECLINING STARS \\
\hline
\end{tabular}

${ }^{14}$ Given the gaps in the available statistics for the categories used to report import flows by country of origin, in order to attain the broadest coverage possible, it was necessary to limit the analysis to 20062008 and to the category "other commercial services" (total service imports minus imports in the "travel" and "transport" categories), which include knowledge-intensive exports but also include other types of external sales. market share in the destination countries/markets (also for 2006-2008).

The data used in this analysis are primarily drawn from the import statistics by country of origin compiled in United Nations Service Trade, which are reported only for the Organization for Economic Cooperation and Development (OECD) countries, plus a few other specific cases (e.g. Slovenia and Slovakia). A first limiting factor in this connection is, clearly, that not all destination markets for Latin American exports are represented in these figures, since they include information only on sales to developed countries and some emerging East European countries. However, even though trade in services within the region is significant in the case of Latin America (as is illustrated by the 2009 IDC study on Chile), in order for the region to expand its exports of services, it will have to target developed markets, since they are the world's main importers. Accordingly, despite the limited geographical coverage of the information provided in figure 4 , it nonetheless provides meaningful inputs for this study. ${ }^{15}$

As may be seen from figure 4, the four Latin American countries for which data are provided increased

\footnotetext{
15 Another factor to be taken into account is that the ways in which firms report the origins and destinations of service exports are subject to the influence of tax and other considerations which can, in part, complicate the interpretation of the data, as it is possible, for example, that a firm may declare exports as being directed to a certain country where a billing office is located while the services are actually exported to another location. However, for the purposes of our analysis, this type of distortion does not alter our findings in any significant way.
} 
TradeCAN analysis of destination markets for Latin American exports of other commercial services, 2006-2008

(Percentage variation)

A. Argentina

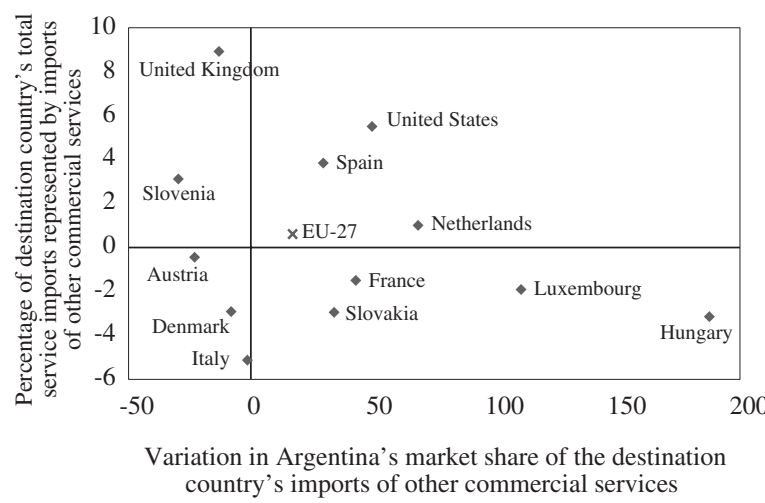

C. Mexico

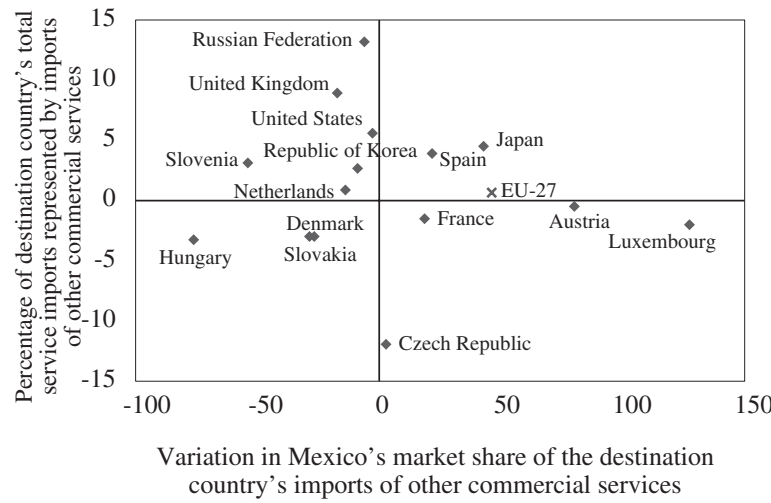

B. Brazil

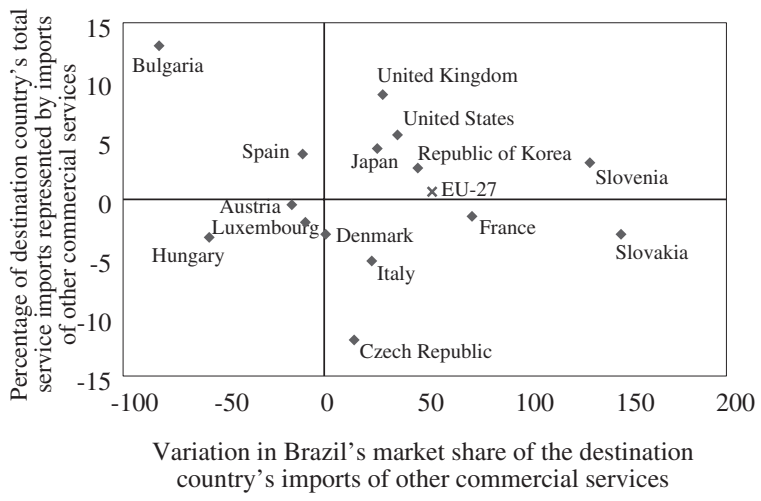

D. Chile

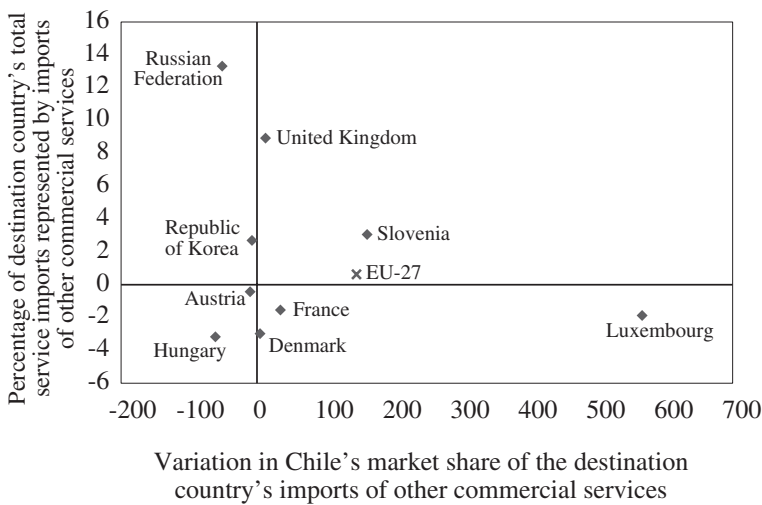

Source: prepared by the authors, on the basis of data from the United Nations Service Trade and the United Nations Conference on Trade and Development (UNCTAD).

EU-27: the economies of the 27 countries of the European Union.

their share in the burgeoning European Union market overall (Argentina and Mexico, in particular, exhibited the same upward trend in the Spanish market). The United States represents a rising star for Argentina and Brazil, but somewhat of a missed opportunity for Mexico. The United Kingdom is a rising star for Brazil and Chile but a missed opportunity for Argentina and Mexico, while Japan figures as a rising star for Brazil and Mexico. In sum, then, the data indicate that, in recent years, although Latin America still lags behind in terms of competitiveness in various areas, a number of Latin American countries have succeeded in gaining ground in major markets for knowledge-intensive service imports.
It has been noted in earlier studies, however, that the region's position in knowledge-intensive services sectors is, for the most part, confined to low-technology or intermediate-technology segments or to segments that are not strategically positioned in the global activities of the corporations that dominate these value chains. This is true of clinical research, engineering and construction, software and outsourcing, all of which exhibit much the same pattern (López, Ramos and Torre, 2009; López, Niembro and Ramos, 2011 and 2012). This situation poses additional challenges for the Latin American countries, which need to climb their way up the global value chains in these sectors. 


\section{IV \\ Determinants of competitiveness in knowledge-intensive services and of Latin America's market position}

Given the findings presented in section III, the next step is to explore the factors that may underlie the region's relatively poor performance in knowledge-intensive services markets. This may point up useful policy lessons that can be drawn upon to help Latin America achieve a larger and stronger position in these sectors.

Reports from major international consulting firms and the findings of a number of different academic studies (Doh, Bunyaratavej and Hahn, 2008; Ramasamy and Yeung, 2010; Capik and Drahokoupil, 2011; Liu, Feils and Scholnick, 2011; Kim, Yoon and Lee, 2012) indicate that costs (especially labour costs) are a decisive factor in decision-making about the outsourcing of services and in export competitiveness. Along these same lines, Eichengreen and Gupta (2012) show that the exchange rate is a key explanatory factor for exports of knowledgeintensive services and that this effect is even greater in the case of goods exports.

The supply of human capital is another decisive factor in decision-making about outsourcing and related FDI (Liu, Feils and Scholnick, 2011; Doh, Bunyaratavej and Hahn, 2008), as well as service exports (Guerrieri and Meliciani, 2005; Nyahoho, 2010; Arora and Bagde, 2011). Goswami and others (2012) find that an ample supply of qualified human capital has a positive impact on service exports and that the return on investment in education is higher in developing countries. It is to be expected that the importance of human capital increases in step with the complexity of offshored economic activities (see Py and Hatem, 2009; Jensen and Pedersen, 2012).

Case studies on determinants of FDI in services also reflect the predominance of the English language (Ceglowski, 2006; Walsh, 2006; Doh, Bunyaratavej and Hahn, 2008; Capik and Drahokoupil, 2011; Goswami and others, 2012; Kim, Yoon and Lee, 2012), while other studies have highlighted the importance of cultural proximity (Bunyaratavej, Hahn and Doh, 2007; Castellacci, 2010; Nefussi and Schwellnus, 2010). The data on the influence of geographical (and time zone) proximity are not as clear cut, since, for some activities, being in the same time zone is an important consideration, whereas, for others (in which, for example, 24-hour per day, 7 days per week, coverage is an asset), locations in different time zones are a plus.

$R \& D$ is also an influential factor in determining the competitiveness of service exports (Popescu and Tachiciu, 2006; Nyahoho, 2010; Seo, Lee and Kim, 2012), as is the availability of suitable ICT infrastructure (Guerrieri and Meliciani, 2005; Doh, Bunyaratavej and Hahn, 2008; Ramasamy and Yeung, 2010; Walsh and Yu, 2010).

Institutional and legal considerations also play a key role in decision-making about outsourcing since, given the intangible and unstandardized nature of certain services, trade in those services often involves information asymmetries (Kimura and Lee, 2006; Kolstad and Villanger, 2007; Kandilov and Grennes, 2010; Liu, Feils and Scholnick, 2011). As a result, less routine, more complex services that have to be personalized or customized are generally offshored to countries with more advanced institutional structures. Information asymmetries can, at least in part, be mitigated by certification arrangements ${ }^{16}$ or by a firm's decision to partner with prestigious local and/or international networks (Conti, Turco and Maggioni, 2010).

How are the Latin American countries positioned in terms of the various factors that contribute to competitiveness in these sectors? One approach to answering this question is to refer to the competitiveness rankings that consultants have developed when surveying potential locations for knowledge-intensive service exports. Table 5 provides an overview of the available information for the countries of the region, including the A.T. Kearney Global Services Location Index (the leader in the field), which indicates that all the countries are badly placed in terms of educational level. This is also the case (except in the case of Chile) for the business environment, which is assessed on the basis of a range

\footnotetext{
16 These arrangements include, for example, the Capability Maturity Model Integration (CMMI) quality assessment system for software and information services, the eSourcing Capability Model for Service Providers (esCM-SP) for business process outsourcing (BPO) and the accreditation awarded by the Joint Commission International for medical tourism.
} 
Latin American countries' rankings in the A.T. Kearney Index, 2011

(Rankings in various categories)

\begin{tabular}{lccccccccc}
\hline & Argentina & Brazil & Chile & Colombia Costa Rica & Mexico & Panama & Uruguay \\
\hline Global index & 30 & 12 & 10 & 43 & 19 & 6 & 34 & 41 \\
1. Business environment & 46 & 30 & 18 & 40 & 25 & 28 & 26 & 29 \\
1.1. Country risk & 44 & 28 & 6 & 43 & 22 & 25 & 26 & 32 \\
1.2. Infrastructure & 34 & 33 & 14 & 28 & 29 & 44 & 20 & 27 \\
1.3. Cultural exposure & 45 & 48 & 44 & 40 & 32 & 33 & 39 & 27 \\
1.4. Intellectual property protection & 48 & 22 & 27 & 29 & 34 & 26 & 38 & 37 \\
2. Labour supply and capacity & 15 & 8 & 24 & 26 & 36 & 14 & 49 & 41 \\
2.1. Relevant experience & 13 & 9 & 19 & 21 & 34 & 14 & 45 & 38 \\
2.2. Size and availability of the labour force & 18 & 4 & 28 & 20 & 41 & 8 & 46 & 42 \\
2.3. Education & 40 & 39 & 29 & 44 & 30 & 34 & 47 & 31 \\
2.4. Language & 12 & 31 & 35 & 36 & 16 & 32 & 38 & 17 \\
3. Financial advantages & 26 & 37 & 27 & 31 & 14 & 20 & 19 & 28 \\
3.1. Labour costs & 23 & 34 & 26 & 29 & 17 & 21 & 15 & 30 \\
3.2. Infrastructure costs & 31 & 50 & 49 & 45 & 12 & 26 & 28 & 37 \\
3.3. Taxes and regulatory costs & 44 & 35 & 6 & 40 & 16 & 25 & 43 & 9 \\
\hline
\end{tabular}

Source: prepared by the authors on the basis of A.T. Kearney, Offshoring Opportunities amid Economic Turbulence. The A.T. Kearney Global Services Location Index, 2011, A.T. Kearney, Inc., 2011.

of factors such as intellectual property and cultural level. The countries of the region turn in a better showing for labour supply and workforce skills. On the rating for languages, only Argentina, Costa Rica and Uruguay are higher up in the ranking. In terms of financial (cost) factors, Costa Rica is in the lead, but Chile and Uruguay make up for their higher labour and infrastructure costs by having lower taxes and less onerous regulations. Upgrades are also needed in ICT infrastructure (quality and cost) in most of the countries of the region. On the other hand, the fact that they are all in the same time zone as parts of the United States makes them prime nearshoring sites for businesses in that country.

The most conspicuous shortcomings appear to have to do with the countries' education systems, since there are a number of areas in which Latin American countries could boost their export capacity if they had more people with the required skills. ${ }^{17}$ As is shown in table 6, Latin America lags behind other regions, and the percentages of the population with a university education vary a great deal within Latin America as well. There are sharp contrasts in terms of scale or volume (Mexico and Brazil, on the one hand, as compared to Costa Rica and Uruguay, at the other extreme, for example), but there are also differences in the percentages of students who choose scientific or technical disciplines and in the percentages who succeed in completing their university

${ }^{17}$ For an in-depth case study of this issue in Argentina, see López, Niembro and Ramos (2013). studies. For example, Colombia's and Argentina's populations are similar in size, but Colombia has more science and engineering graduates than Argentina does, and Chile has nearly as many as Argentina even though its population is much smaller. Overall, however, the percentage of science and engineering graduates in the region is quite low, which is one of the reasons why it can be so difficult to overcome or redress shortages of skilled workers in certain segments of the knowledgeintensive service sector.

There is also a gap in terms of the quality of education in Latin America, as is demonstrated by the test scores recorded by the OECD Programme for International Student Assessment (PISA). For the 2009 examination, the 8 Latin American countries that took part ranked in the bottom 20 out of the 65 countries that participated in PISA in the mathematics and sciences segments (with the exception of Chile in the latter case).

Finally, as is well known, the region's innovations systems are in difficulty, as is indicated, for example, by the poor performance reflected in such indicators as R\&D expenditure and patents.

While problems in relation to human capital and the shortcomings of the region's innovations systems are broader in nature and have a widespread impact on the structure of the regional economy, the preceding discussion clearly shows that these problems are a particularly serious obstacles to Latin America's progressive entry into knowledge-intensive value chains and especially into the more sophisticated segments of those chains. 


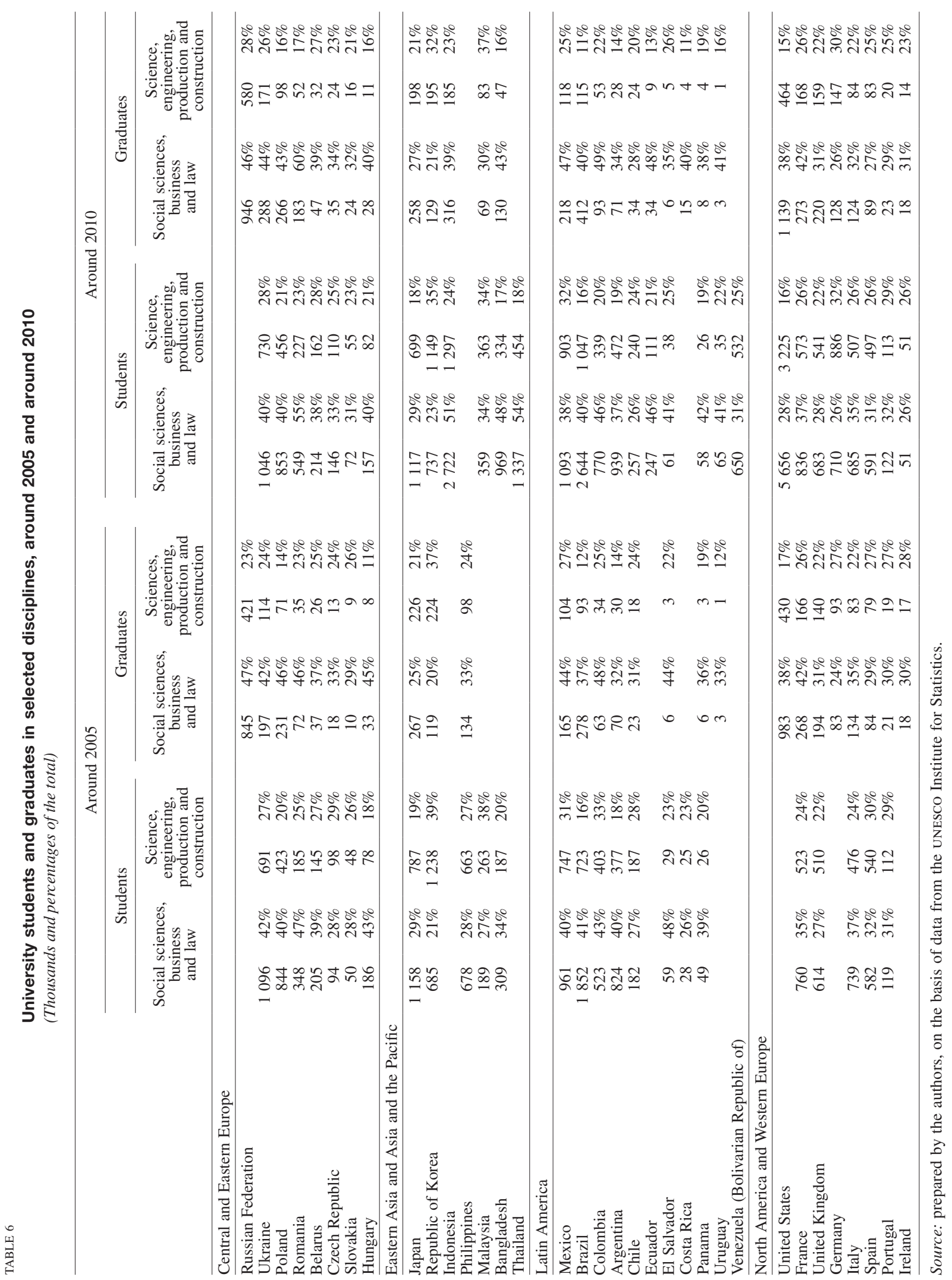




\section{V}

\section{Concluding observations}

The objective of this analysis has been to supplement earlier studies, most of which have focused primarily on an analysis of revealed (static) comparative advantages by providing inputs for a dynamic approach to building the region's competitiveness in the international market for knowledge-intensive services as a means of.

In recent years, some Latin American countries have managed to gain ground in world trade in knowledgeintensive services by expanding their market shares and gaining entry into major import markets for these services. In addition, the relative share of knowledge-intensive services has been on the rise as they gradually displace a portion of the region's more traditional service exports.

Nevertheless, the share of total sales of services represented by knowledge-intensive services still tends to be significantly smaller than is the case for other developing countries (such as those of Asia or Eastern Europe), as is indicated by the fairly small percentage of rising stars identified in the TradecAN-based study presented here. This is partly due to the fact that the pattern of the region's services exports still reflects a high degree of reliance on the more traditional sectors (transport and especially travel, which are segments of world trade that are on the decline). It is also probable that - unlike other nations that began to offshore services earlier on- a number of Latin American countries are still in the early learning stages, as they are just beginning to enter these new markets. If this is the case, then it may be that, while this trend is deepening throughout the region, this will not become readily apparent until a few more years have passed. In order for this to occur, however, certain basic conditions that underpin the competitiveness of these sectors must be maintained. Be this as it may, the fact remains that the business services category figures prominently among the missed opportunities of some Latin American countries; this is a worrisome development, since business services are the biggest market, by volume, at the global level.

The region's prospects for the future appear to be bright. All the available projections indicate that knowledge-intensive service markets are going to continue to grow at a rapid pace (see, for example, Muthal, 2011 and Volek, 2012), and Latin America has a series of advantages that put it in a good position to expand its share of international trade in knowledge-intensive services: (i) lower costs than the developed countries in terms of wages, real property and infrastructure; (ii) a supply of skilled human resources that, while it does not compare in quantity or quality to that of some Asian or Easter European countries, is nonetheless sufficient for the development of many of the activities involved in the knowledge-intensive service sectors; and (iii) geographic proximity (and shared time zones) with the United States and a greater cultural proximity to North America and Europe than its Asian competitors. The region can use these general attributes to leverage its export specialization in these sectors.

Nevertheless, Latin America - and, in particular, the countries that have made the most headway in these sectors - is now faced with the challenge of holding on to the positions it has won and then strengthening them further by developing certain assets that will help it to scale the various global value chains and begin to gain ground in the more technologically sophisticated and knowledge-intensive segments, where the region's presence is still quite limited.

Making inroads into the more sophisticated links in the services chain (while gradually moving out of the commoditized activities, which include most of the ones in the BPO category) is a formidable challenge. To do so, the region will have to expand and upgrade its supply of human capital so that it can consolidate other types of advantages, above and beyond those based on low costs. These new advantages will need to be based on specific assets, talents and capacities that will enable the region to take up differentiated positions in these sectors. While there are a few cases in which this is already happening, they are as yet only scattered examples and are far from becoming a consolidated trend. This comes as no surprise, given the complexity of the task and the long time involved.

It is therefore important to bear in mind that, if integration into global value chains and the services trade hinges on the existence of low labour costs, then the countries' efforts to gain entry into those chains could, if successful, soon create obstacles to their continued progress. In other words, as the export of services drives up the per capita income of the exporting country (or as that export activity generates bottlenecks in the supply of human resources for the most dynamic services sectors), wages will have to rise, and this rise in costs will have to be matched by commensurate productivity gains if 
the exporting country is to maintain its competitive position in the international economy. However, since much the same types of technologies are used in the production of many knowledge-intensive services around the world (basically ICTs and easily transferable organizational routines), it does not seem plausible that cross-country productivity differentials could be so large as to enable countries with high or rising labour costs to remain competitive in offshored services. Clearly, this is all much less likely if competition is based on other differentiating factors that are not easily replicated by competitor countries. The search for a dynamic, sustainable pattern of service export activity for Latin American countries should therefore be focused on bolstering these sorts of factors and finding appropriate niche markets.

\section{Bibliography}

A.T. Kearney (2011), Offshoring Opportunities amid Economic Turbulence. The A.T. Kearney Global Services Location Index, 2011 , A.T. Kearney, Inc.

Arora, A. and S. Bagde (2011), "Private investment in human capital and industrial development: the case of the Indian software industry", Dimensions of Economic Theory and Policy: Essays for Anjan Mukherji, K. Dastidar, H. Mukhopadhyay and U. Sinha (eds.), Oxford, Oxford University Press.

Baldwin, R. (2011), "Trade and industrialization after globalization's 2nd unbundling: how building and joining a supply chain are different and why it matters", NBER Working Paper, No. 17716, Cambridge, Massachusetts, National Bureau of Economic Research.

Bianco, C. (2007), “¿De qué hablamos cuando hablamos de competitividad?", Working Paper, No. 31, Buenos Aires, Centre for Studies in Science, Development and Higher Education.

Bobirca, A. and P.G. Miclaus (2007), "A multilevel comparative assessment approach to international services trade competitiveness: the case of Romania and Bulgaria", International Journal of Human and Social Sciences, vol. 1, No. 1, World Academy of Science Engineering and Technology.

Borchert, I. and A. Mattoo (2010), "The crisis-resilience of services trade", The Service Industries Journal, vol. 30, No. 13, Taylor $\&$ Francis.

Bunyaratavej, K., E. Hahn and J.P. Doh (2007), "International offshoring of services: a parity study", Journal of International Management, vol. 13, No. 1, Amsterdam, Elsevier.

Capik, P. and J. Drahokoupil (2011), "Foreign direct investments in business services: transforming the Visegrád four region into a knowledge-based economy?", European Planning Studies, vol. 19, No. 9, Taylor \& Francis.

Castellacci, F. (2010), "The internationalization of firms in the service industries: Channels, determinants and sectoral patterns", Technological Forecasting and Social Change, vol. 77, No. 3, Amsterdam, Elsevier.

Ceglowski, J. (2006), "Does gravity matter in a service economy?", Review of World Economics, vol. 142, No. 2, Springer.

Chudnovsky, D. and F. Porta (1990), "La competitividad internacional. Principales cuestiones conceptuales y metodológicas", Working Paper, No. 3, Buenos Aires, Research Centre for Industrial Transformation.

Conti, G., A.L. Turco and D. Maggioni (2010), "Exporters in services: new evidence from Italian firms", Applied Economics Quarterly, vol. 56, No. 1, Berlin, Duncker \& Humblot.

Díaz de la Guardia, C., J. Molero and P. Valadez (2005), "International competitiveness in services in some European countries: basic facts and a preliminary attempt of interpretation", Working Paper, No. 01/05, Madrid, Complutense Institute of International Studies, Complutense University of Madrid.

Doh, J.P., K. Bunyaratavej and E.D. Hahn (2008), "Separable but not equal: the location determinants of discrete services offshoring activities", Journal of International Business Studies, vol. 40, No. 6, Palgrave Macmillan.
Eichengreen, B. and P. Gupta (2012), "The real exchange rate and export growth: are services different?", MPRA Paper, No. 43358, Munich, University Library of Munich.

Escaith, H. (2008), "Measuring trade in value added in the new industrial economy: statistical implications", MPRA Paper, No. 14454, Munich, University Library of Munich.

Fernández-Stark, K., P. Bamber and G. Gereffi (2011), The Offshore Services Global Value Chain: Economic Upgrading and Workforce Development, Durham, Center on Globalization, Governance \& Competitiveness, Duke University.

Ferraz, J.C., D. Kupfer and L. Haguenauer (1996), Made in Brazil: Desafios competitivos para a indústria, Rio de Janeiro, Editora Campus.

Ffrench-Davis, R. (1990), "Ventajas comparativas dinámicas: Un planteamiento neoestructuralista", Cuadernos de la CEPAL, No. 63, Santiago, Chile, Economic Commission for Latin America and the Caribbean (ECLAC).

Gereffi, G. and K. Fernández-Stark (2010a), The Offshore Services Global Value Chain, Durham, Center on Globalization, Governance \& Competitiveness, Duke University.

(2010b), "The offshore services value chain: developing countries and the crisis", Policy Research Working Paper, No. 5262, Washington, D.C., World Bank.

Goswami, A.G. and others (2012), "Service exports: are the drivers different for developing countries?", Exporting Services: A Developing Country Perspective, A.G. Goswami, A. Mattoo and S. Saez (eds.), Washington, D.C., World Bank.

Guerrieri, P. and V. Meliciani (2009), "Internationalization, Technology and Business Services Specialization in Europe", Rome.

(2005), "Technology and international competitiveness: the interdependence between manufacturing and producer services", Structural Change and Economic Dynamics, vol. 16, No. 4, Amsterdam, Elsevier.

IDC (2009), "La industria de servicios globales en Chile", Santiago, Chile, Production Development Corporation (CORFO).

Jensen, P. and T. Pedersen (2012), "Offshoring and international competitiveness: antecedents of offshoring advanced tasks", Journal of the Academy of Marketing Science, vol. 40, No. 2, Springer.

Jiang, W. (2011), "Comparative Analysis on the Competitiveness of Service Trade in China and Japan and Its Enlightenments for China”, 2011 International Conference on Management and Service Science (MASS).

Kandilov, I.T. and T. Grennes (2010), "The determinants of service exports from Central and Eastern Europe", Economics of Transition, vol. 18, No. 4, Wiley.

Kim, Y.-D., S. Yoon and K.S. Lee (2012), "International competitiveness of Korea service industry", American Journal of Applied Sciences, vol. 9, No. 3, Science Publications.

Kimura, F. and H.H. Lee (2006), "The gravity equation in international trade in services", Review of World Economics, vol. 142, No. 1, Springer. 
Kolstad, E. and I. Villanger (2007), "Determinants of foreign direct investment in services", European Journal of Political Economy, vol. 24, No. 2, Amsterdam, Elsevier.

Langhammer, R.J. (2004), "Revealed comparative advantages in the services trade of the United States, the European Union and Japan: what do they tell us?", The Journal of World Investment \& Trade, vol. 5 , No. 6

Liu, R., D. Feils and B. Scholnick (2011), "Why are different services outsourced to different countries?", Journal of International Business Studies, vol. 42, Palgrave Macmillan.

López, A. and D. Ramos (2013), “¿Pueden los servicios intensivos en conocimiento ser un nuevo motor de crecimiento en América Latina?", Revista Iberoamericana de Ciencia, Tecnología y Sociedad, vol. 8, No. 24, Buenos Aires, Centre for Studies in Science, Development and Higher Education.

(coords.) (2010), La exportación de servicios en América Latina: Los casos de Argentina, Brasil y México, Montevideo, MERCOSUR Economic Research Network.

López, A., A. Niembro and D. Ramos (2013), "Cadenas globales de valor, offshoring de servicios y rol de los recursos humanos: Lecciones de la Argentina", El sistema argentino de innovación: Instituciones, empresas y redes. El desafío de la creación y apropiación de conocimiento, D. Suárez (ed.), Los Polvorines, Buenos Aires, Ediciones UNGS.

(2012), "Posibilidades de inserción de los países de América Latina en cadenas globales de valor en servicios: Un análisis de las políticas de promoción de exportaciones y atracción de inversiones", Santiago, Chile, Economic Commission for Latin America and the Caribbean (ECLAC).

(2011), "Global value chains in the services sector: business strategies and latin american insertion", Integration and Trade, vol. 15, No. 32, Washington, D.C., Inter-American Development Bank, January/June.

López, A. and others (2010), "El comercio mundial de servicios de salud", La exportación de servicios en América Latina: Los casos de Argentina, Brasil y México, A. López and D. Ramos (coords.), Montevideo, Mercosur Research Economic Network.

López, A., D. Ramos and I. Torre (2009), "Las exportaciones de servicios de América Latina y su integración en las cadenas globales de valor", Projects Document, No. 37 (LC/W.240), Santiago, Chile, Economic Commission for Latin America and the Caribbean (ECLAC).
Muthal, H. (2011), "Realizing Opportunities. The Global IT-BPO Sector and the Potential of Latin America \& the Caribbean", Tholons Inc.

Nefussi, B. and C. Schwellnus (2010), "Does FDI in manufacturing cause FDI in business services? Evidence from French firmlevel data", Canadian Journal of Economics, vol. 43, No. 1, Quebec, Canadian Economics Association.

Nyahoho, E. (2010), "Determinants of comparative advantage in the international trade of services: an empirical study of the HecksherOhlin approach", Global Economy Journal, vol. 10, No. 1.

Popescu, N. and L. Tachiciu (2006), "Research and development as a determinant of services sector competitiveness", Journal for Economic Forecasting, vol. 3, No. 4.

Porta, F. (2005), "Especialización productiva e inserción internacional. Evidencias y reflexiones sobre el caso argentino", project FO/ ARG/05/012, United Nations Development Programme (UNDP).

Py, L. and F. Hatem (2009), "Where do multinationals locate service and manufacturing activities in Europe and why?", Économie et statistique, No. 426.

Ramasamy, B. and M. Yeung (2010), "The determinants of foreign direct investment in services", World Economy, vol. 33, No. 4, Wiley Blackwell.

Seo, H.-J., Y.S. Lee and H.S. Kim (2012), "The determinants of export market performance in Organisation for Economic Cooperation and Development service industries", The Service Industries Journal, vol. 32, No. 8, Taylor \& Francis.

Seyoum, B. (2007), "Revealed comparative advantage and competitiveness in services. A study with special emphasis on developing countries", Journal of Economic Studies, vol. 34, No. 5, Emerald.

Volek, T. (2012), "Global Off Shoring and Outsourcing Market Dynamics", 2012 sofTECON Conference, Bratislava, 15 March.

Walsh, K. (2006), "Trade in services: does gravity hold? A gravity model approach to estimating barriers to services trade", Discussion Paper Series, No. 183, Institute for International Integration Studies.

Walsh, J.P. and J. Yu (2010), "Determinants of foreign direct investment: a sectoral and institutional approach", IMF Working Paper, No. 10/187, Washington, D.C., International Monetary Fund.

Zhang, B., N. Wei and Y. Miao (2010), "China's Service Trade Competitiveness and its Development Strategies", document presented at the 2010 WASE International Conference on Information Engineering. 